\title{
Second-generation endoscopic ultrasound elastography in the differential diagnosis of solid pancreatic masses. Pancreatic cancer $v s$. inflammatory mass in chronic pancreatitis
}

\author{
J. J. Iglesias García ${ }^{1,2}$, J. Lariño Noia ${ }^{1,2}$, A. Álvarez Castro ${ }^{1,2}$, B. Cigarrán ${ }^{2,3}$ and J. E. Domínguez Muñoz ${ }^{1,2}$ \\ ${ }^{1}$ Gastroenterology Department. ${ }^{2}$ Foundation for Research in Digestive Diseases. University Hospital of Santiago de \\ Compostela. A Coruña, Spain. ${ }^{3}$ Internal Medicine Department. Virxe da Xunqueira Hospital. Cee, A Coruña. Spain
}

\begin{abstract}
Endoscopic ultrasonography (EUS) is considered one of the most accurate methods for the diagnosis and staging of pancreatic tumors. EUS-guided fine-needle aspiration (FNA) allows to increase the diagnostic accuracy of EUS in this setting; however, it is technically demanding (a pathologist is also essential) and is furthermore associated with small, but not insignificant morbidity. EUS pancreatic elastography, by analyzing tissue stiffness, arises as a new and very useful tool for the differential diagnosis of solid pancreatic masses. Elastography provides specific patterns supporting the benign or malignant nature of the disease. However, there is a handicap related to the subjective interpretation of images. Second-generation elastography has been recently developed, and allows a quantitative analysis of tissue stiffness. It is based on the determination of a strain ratio (obtained after comparing the strain value of the mass to a strain value from a control area in the region under study). We present two cases reflecting the usefulness of second-generation elastography in the differential diagnosis between pancreatic adenocarcinoma and an inflammatory mass in the context of chronic pancreatitis. We found significant differences between both masses in the strain ratio values $(25.46 \%$ in the pancreatic adenocarcinoma $v s$. $2.35 \%$ in the inflammatory mass). Second-generation elastography is a very useful tool for the differential diagnosis of solid pancreatic masses.
\end{abstract}

Key words: Endoscopic ultrasound. Elastography. Second-generation Elastography. Pancreatic tumors.

Received: $15-12-08$

Accepted: 19-12-08.

Correspondence: Julio Iglesias García. Servicio de Aparato Digestivo. Foundation for Research in Digestive Diseases (FIENAD). Hospital Universitario de Santiago de Compostela. C/ Choupana, s/n. 15706 Santiago de Compostela. A Coruña, Spain.e-mail: julioiglesiasgarcia@hotmail.es
Iglesias García J, Lariño Noia J, Álvarez Castro A, Cigarrán B, Domínguez Muñoz JE. Second-generation endoscopic ultrasound elastography in the differential diagnosis of solid pancreatic masses. Pancreatic cancer vs. Inflammatory mass in chronic pancreatitis. Rev Esp Enferm Dig 2008; 100: 723-730.

\section{INTRODUCTION}

Endoscopic ultrasonography (EUS) has become a basic tool for the study of pancreatic diseases, and is considered one of the most accurate methods for the diagnosis and staging of both chronic inflammatory and neoplastic pancreatic diseases $(1,2)$. However, differentiation between pancreatic cancer and focal pancreatitis remains a challenge. EUS can guide fine-needle aspiration (EUS-FNA) for the collection of cytological samples from pancreatic lesions with a very high overall diagnostic accuracy (3-7). EUS-FNA may be, however, technically demanding, and multiple puncturing of pancreatic lesions may be needed to obtain adequate material for cytological or microhistological evaluation. EUS-FNA of the pancreas, despite being considered very safe, is furthermore associated with a small, but not insignificant morbidity $(8,9)$.

Elastography is a method for the real-time evaluation of tissue stiffness, which has been used for the analysis of superficial organ lesions such as those of the breast (1013). Images obtained by elastography represent tissue elasticity, which may reflect histopathological differences (14). The association of this technology with EUS has implied a significant advance in the management of pancreatic diseases, mainly in the differential diagnosis of pancreatic tumors (15). 
A new advance has been recently developed - secondgeneration elastography. This technique allows not only a qualitative elastographic analysis, but also a quantitative analysis based on the determination of a strain ratio (obtained after comparing the strain value of the mass to a strain value from a control area in the region under study). Data published on this new technique are scarce. We present two cases reflecting the usefulness of secondgeneration elastography in the differential diagnosis of solid pancreatic masses. One of these cases is a patient with pancreatic cancer, the other is a patient with an inflammatory mass in the context of chronic pancreatitis.

\section{METHODS}

EUS was performed with a linear EUS probe (EG 3830 UTK; Pentax Europe GmbH, Hamburg, Germany) attached to the EUB 900 (Hitachi Medical Systems $\mathrm{GmbH}$, Wiesbaden, Germany) platform, which includes the elastography module. This module enables real-time elastographic evaluation and recording. The technology is based on the detection of small structure deformations within the B-mode imaging caused by compression, so that the strain is smaller in hard tissue than in soft tissue (13). The degree of deformation is used as an indicator of tissue stiffness $(14,16)$. Different elasticity values are marked with different colors, resulting in different tissue elasticity patterns. The system is set up to use a hue color map (red-green-blue) where hard tissue areas are shown in dark blue, moderately hard tissue areas in cyan, intermediate tissue areas in green, moderately soft tissue areas in yellow, and soft tissue areas in red (17). EUS elastography was performed by using a two-panel image with the usual conventional grey-scale B-mode EUS image on the right side and the elastographic image on the left side. The region of interest (ROI) for the elastographic evaluation was manually selected and included the whole targeted lesion when possible, as well as surrounding tissues, which were used for control (15). For the performance of second-generation elastography, also developed by Hitachi, two different areas (A and B) from the region of interest were selected for the quantitative elastographic analysis: area $\mathrm{A}$ is representative of a mass and area $\mathrm{B}$ refers to a soft reference area. The B/A quotient (strain ratio) is considered the result of the elastographic evaluation.

To obtain elastographic images, the probe was pressed against the wall with only the pressure needed for an optimal and stable B-mode image at 7.5 MHz. Since elastography images tend to show rapid changing colors, a stable image for at least five seconds was required for final pattern definition.

Once EUS elastography was performed and the elastographic pattern defined, a EUS-FNA procedure of the pancreatic mass was carried out in both patients with a 22-gauge needle (Echo-Tip from Wilson-cook Medical,
Winston-Salem, North Carolina, USA; and Sonotip II, Mediglobe, Germany) in order to obtain a final diagnosis.

\section{CASE REPORTS}

\section{Case 1}

A 43-year-old woman with a medical history of meningitis in childhood, gestational diabetes, and gravidic cholestasis, and previously diagnosed with idiopathic chronic pancreatitis was admitted to our department for epigastric abdominal pain associated with jaundice for the last 48 hours. A CT scan was performed, which identified multiple pancreatic calcifications with an enlarged head of the pancreas (reaching $6 \mathrm{~cm}$ in diameter) and duodenal infiltration. There was also a slight dilation of the main pancreatic duct, as well as enlarged periaortic and mesenteric lymph nodes. The first diagnosis established was suspicion of an inflammatory mass in the context of chronic pancreatitis, but with concern regarding degeneration towards pancreatic cancer. EUS was performed, which confirmed the presence of a heteroechogenic, irregular mass at the head of the pancreas with calcifications both inside the mass and across the remaining parenchyma. The pancreatic parenchyma also presented with hyperechoic foci, hyperechoic strands and lobularity with honeycombing (characteristic of chronic pancreatitis). The main pancreatic duct was dilated with a

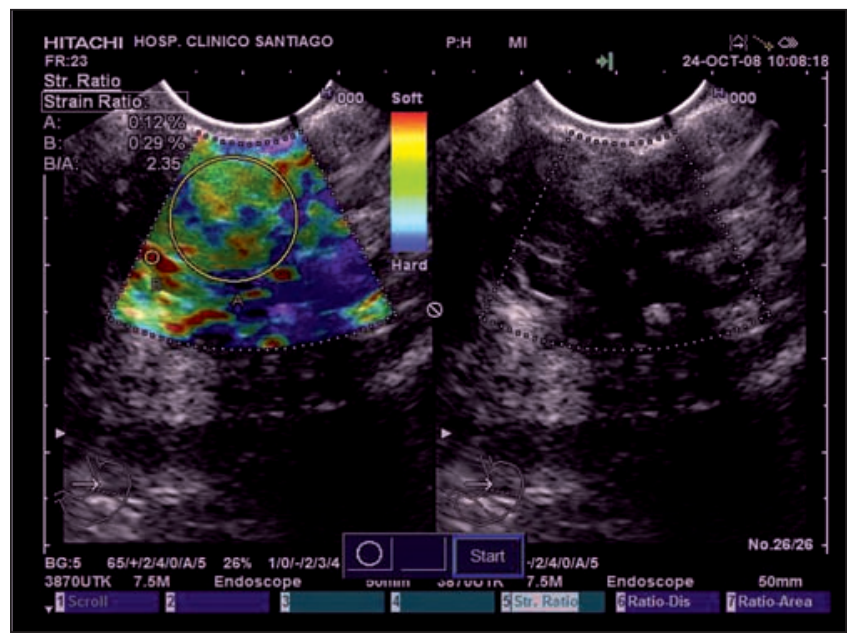

Fig. 1. Second-generation elastographic study (quantitative evaluation) of a mass located at the head of the pancreas that in the baseline study showed a heterogeneous green-predominant pattern with a strain ratio of 2.35 , and an A value (corresponding to the mass) of $0.12 \%$. These findings are characteristic of inflammatory masses, and allow the exclusion of malignancy.

Estudio elastográfico de segunda generación (evaluación cuantitativa) de la masa localizada a nivel de cabeza pancreática, apreciándose en el estudio basal un patrón heterogéneo de predominio verde, con un coeficiente de elasticidad de 2,35 y una valor de A (lesión a estudio) de $0,12 \%$. Estos hallazgos son característicos de las lesiones inflamatorias, permitiendo excluir malignidad. 
hyperechoic wall and dilated side branches. The pancreatic mass infiltrated and dilated the common bile duct. An elastographic evaluation was performed during EUS. In the baseline study the mass had a heterogeneous green-predominant pattern with scarce yellow and red lines; in the second-generation analysis the strain ratio was 2.35, with an A value (corresponding to the mass) of $0.12 \%$. A EUS-FNA procedure was performed, which showed the characteristic changes of an inflammatory mass in the context of chronic pancreatitis (18). Finally, an endoscopic retrograde cholangio-pancreatography (ERCP) was performed, and a plastic stent was placed. The patient evolved satisfactorily, and after three months of follow-up she remains stable and asymptomatic.

\section{Case 2}

A 79-year-old man with a medical history of hypertensive cardiopathy with atrial fibrillation and transitionalcell bladder cancer, a smoker of 20 cigarettes a day until 70 years of age, and a previous drinker of $80 \mathrm{~g}$ of ethanol per day, was admitted to our department for epigastric abdominal pain associated with weight loss $(8 \mathrm{~kg}$ over the last two months) for the last 3 weeks. A helical CT scan was performed, which identified an irregular, 3-cm lesion located at the head of the pancreas, with vascular infiltration (mainly porto-mesenteric axis, with a significant alteration on the color-doppler signal) and enlarged peri-

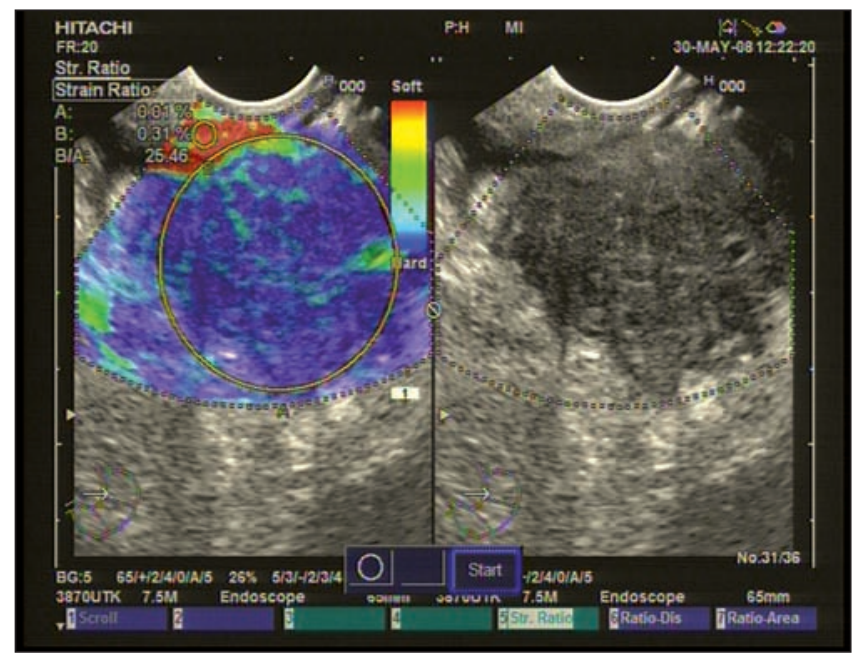

Fig. 2. Second-generation elastographic study (quantitative evaluation) of a pancreatic tumor located at the head of the pancreas that in the baseline study had a heterogeneous blue-predominant pattern, and a geographic appearance, with a strain ratio of 25.46 and an A value (corresponding to the mass) of $0.01 \%$. These findings significantly support the malignant nature of the tumor.

Estudio elastográfico de segunda generación (evaluación cuantitativa) de la lesión pancreática, localizada a nivel de transición cabeza-cuerpo de páncreas, con un patrón basal heterogéneo de predominio azul con distribución geográfica, mostrando un coeficiente de elasticidad de 25,46 y una valor de A (lesión a estudio) de 0,01\%. Estos hallazgos apoyan de forma significativa el diagnóstico de malignidad. pancreatic and celiac-trunk lymph nodes (hypoechoic, rounded, bigger than $1 \mathrm{~cm}$, suggesting tumoral origin). The first diagnosis established was suspicion of a pancreatic tumor, probably pancreatic adenocarcinoma. A EUS procedure was performed, which confirmed the presence of a solid, irregular, poorly echogenic mass at the head of the pancreas. EUS also confirmed the vascular infiltration. The elastographic evaluation was performed during EUS. In the baseline study the mass had a heterogeneous blue-predominant pattern with scarce green areas and red lines, and a geographic appearance; in the second-generation analysis the strain ratio was 25.46 , with an A value (corresponding to the mass) of $0.01 \%$. A EUS-FNA procedure was performed, which confirmed the diagnosis of pancreatic adenocarcinoma. The patient was referred to Oncology because the tumor was considered unresectable due to vascular infiltration and the patient nonoperable because of his cardiovascular disease. After three months of follow-up the patient exhibits tumor progression (in the last control visit liver metastases were found) and under palliative treatment.

\section{DISCUSSION}

Elastography allows a real-time evaluation of tissue stiffness or hardness using conventional ultrasound equipments. Some pathological conditions, like malignant tumors, often induce changes in the mechanical properties of tissues. Elasticity is usually uniform in benign lesions; however, malignant tumors grow in a much disorganized way, and present with heterogeneous elasticity throughout the tumor (19). In this context, the association of this technology with EUS means a significant advance in the management, for instance, of pancreatic diseases. EUS-elastography has demonstrated its usefulness in the diagnosis of chronic pancreatitis, and mainly in the differential diagnosis of pancreatic tumors (15).

Up to now, few studies on the usefulness of EUS-elastography in the differential diagnosis of solid pancreatic tumors have been reported. However, almost all of these studies have the same problem - the handicap of being based on a subjective interpretation of the color pattern obtained during conventional elastographic evaluation. In the first study, published by Giovannini et al., elastography showed a sensitivity of $100 \%$ and a specificity of $67 \%$ to determine the malignant nature of solid pancreatic tumors. In this study, malignant lesions had mainly a blue color pattern, whereas other color patterns were considered benign. They were able to correctly identify all patients with malignant tumors; however, some benign masses were also classified as malignant. They proposed a new classification based on the predominant color and image pattern (20). Afterwards, in a study performed by our group in 80 pancreatic solid lesions and 10 healthy controls, four different elastographic patterns could be observed. A homogeneous green elastographic pattern 
was only seen in all 10 normal pancreas controls. A heterogeneous green-predominant elastographic pattern was seen in 18 of the 23 inflammatory masses, and in none of the malignant tumors. A heterogeneous blue-predominant pattern with a geographic appearance was seen in 48 pancreatic adenocarcinomas and in a metastatic tumor, but also in five inflammatory masses. Finally, a homogeneous blue elastographic pattern was identified only in all 8 cases of neuroendocrine tumors. With these findings, EUS-elastography showed a sensitivity of $100 \%$, a specificity of $78 \%$, and an overall accuracy of $93.7 \%$ in the evaluation of solid pancreatic tumors (21). However, Jansen et al. showed not-so-optimistic results. In a subanalysis performed in their study, including only patients with solid pancreatic masses, they described in all of them a similar pattern, mixed heterogeneous green and blue, with an irregular distribution, except in cases of endocrine tumors (with more homogeneous patterns). However, they only included one inflammatory mass in the context of chronic pancreatitis, and it was thus difficult to compare with previous studies, which included a significant, higher number of inflammatory masses (22). Similar data are presented in a recent study including 70 patients with solid pancreatic tumors, and 10 healthy controls. Authors could only complete the elastographic evaluation in $56 \%$ of patients, mainly related to the difficulty of delimiting the region of interest in tumors greater than $35 \mathrm{~mm}$, or in those far away from the transducer, as they could not include enough surrounding tissue for control purposes. They obtained a diagnostic sensitivity of $41 \%$ and a specificity of $53 \%$ with an overall accuracy of $45 \%$, clearly worse than in previous studies (23). However, it is important to point out that all 58 tumors included in the study were malignant, without a single benign lesion. Globally, all these studies presented an important limitation; they were all based on a subjective interpretation of a color-predominant pattern. Probably this fact is one of the clues explaining the different results obtained in previous studies. This is the reason why an objective and reproducible evaluation may avoid the bias related to subjective interpretations.

At present, there is a system available allowing a quantitative evaluation of tissue stiffness by determining a strain ratio - second-generation elastography. This is a new and important advance in the differential diagnosis of solid pancreatic tumors. We present in this article our initial experience. We report two cases, an inflammatory mass in the head of the pancreas, and a pancreatic adenocarcinoma, both evaluated with this new technique. We have detected that the strain ratio in the inflammatory mass was significantly lower that the strain ratio of the pancreatic adenocarcinoma (2.35 vs. 25.46). We also found that the A value, corresponding to the mass, was significantly higher in the inflammatory mass as compared to the pancreatic adenocarcinoma (0.12 vs. $0.01 \%)$. It seems possible to differentiate both lesions, not only by the subjective interpretation of the color-patterns but also in an objective way using second-generation elastography. Another advance in this setting is worth mentioning. Saftoiu et al. (23) have recently published their results with a novel method based on a specially designed software, which allows a quantitative analysis by calculating hue histograms for each individual elastographic image. They included 22 normal pancreas controls, 11 patients with chronic pancreatitis, 32 pancreatic adenocarcinomas, and 3 neuroendocrine tumors. Using a cut-off of 175 points, they could differentiate between benign and malignant pancreatic lesions with a sensitivity, specificity, and accuracy of 91.4, 87.9 and $89.7 \%$, respectively (24).

We can conclude that second-generation elastography shows promising data as a useful tool for the differential diagnosis of solid pancreatic tumors (mainly to differentiate benign from malignant lesions). In our initial experience, we obtained significantly different values between a benign inflammatory mass (in the context of chronic pancreatitis) and a malignant pancreatic tumor (pancreatic adenocarcinoma). However, new prospective studies are needed to confirm the usefulness of this new technique in this setting.

\section{REFERENCES}

1. Mertz HR, Sechopoulos P, Delbeke D, Leach SD. EUS, PET, and CT scanning for evaluation of pancreatic adenocarcinoma. Gastrointest Endosc 2000; 52: 367-71.

2. Soriano A, Castells A, Ayuso C, Ayuso JR, de Caralt MT, Gines MA, et al. Preoperative staging and tumour resectability assessment of pancreatic cancer: prospective study comparing endoscopic ultrasonography, helical computed tomography, magnetic resonance imaging, and angiography. Am J Gastroenterol 2004; 99: 492-501.

3. Varadarajulu S, Tamhane A, Eloubeidi MA. Yield of EUS-guided FNA of pancreatic masses in the presence or the absence of chronic pancreatitis. Gastrointest Endosc 2005; 62: 728-36.

4. Chang KJ, Nguyen P, Erickson RA, Durbin TE, Katz KD. The clinical utility of endoscopic ultrasound-guided fine-needle aspiration in the diagnosis and staging of pancreatic carcinoma. Gastrointest Endosc 1997; 45: 387-93.

5. Harewood GC, Wiersema MJ. Endosonography-guided fine needle aspiration biopsy in the evaluation of pancreatic masses. Am J Gastroenterol 2002; 97: 1386-91.

6. Iglesias-García J, Dominguez-Muñoz JE, Lozano-Leon A, Abdulkader I, Lariño-Noia J, Antunez J, et al. Impact of endoscopic-ultrasound fine needle biopsy for diagnosis of pancreatic masses. World J Gastroenterol 2007; 13: 289-93.

7. Varas MJ, Miquel JM, Abad R, Espinos JC, Cañas MA, Fabra R, et al. Interventionist endoscopic ultrasonography. A retrospective analysis of 60 procedures. Rev Esp Enferm Dig 2007; 99: 138-44.

8. Micames C, Jowell PS, White R, Paulson E, Nelson R, Morse M, et al. Lower frequency of peritoneal carcinomatosis in patients with pancreatic cancer diagnosed by EUS-guided FNA vs percuteneous FNA. Gastrointest Endosc 2003; 58: 690-5.

9. Eloubeidi MA, Tamhane A, Varadajulu S. Frequency of major complications after EUS-guided FNA of solid pancreatic masses: a prospective evaluation. Gastrointest Endosc 2006; 63: 622-9.

10. Céspedes I, Ophir J, Ponnekanti H, Maklad N. Elastography: elasticity imaging using ultrasound with application to muscle and breast in vivo. Ultrasound Imaging 1993; 15: 73-88.

11. Garra BS, Céspedes EI, Ophir J, Spratt SR, Zuurbier RA, Magnant $\mathrm{CM}$, et al. Elastography of breast lesions: initial clinical results. Radiology 1997; 202: 79-86. 
12. Bercoff J, Chaffai S, Tanter M, Sandrin L, Catheline S, Fink M, et al. In vivo breast tumour detection using transient elastography. Ultrasound Med Biol 2003; 29: 1387-96.

13. Itoh A, Ueno E, Tohno E, Kamma H, Takahashi H, Shiina T, et al. Breast disease: clinical application of US elastography for diagnosis Radiology 2006; 239: 341-50.

14. Frey H. Real-time elastography. A new ultrasound procedure for the reconstruction of tissue elasticity. Radiologie 2003; 43: 850-5.

15. Iglesias-García J, Lariño-Noia J, Domínguez-Muñoz JE. Elastografía pancreática. Gastroenterología y Hepatología Continuada 2009 (en prensa).

16. Gao L, Parker KJ, Lerner RM, Levinson SF. Imaging of the elasticity properties of tissue-a review. Ultrasound Med Biol 1996; 22: 959-77.

17. Frey H, Dietrich CF. Sonoelastography: a new ultrasound modality for assessing tissue elasticity. En: Dietrich CF, editor. Endoscopic ultrasound. An introductory manual and atlas. Sttugart-New York: Thieme; 2006. p. 65-70.

18. Iglesias-Garcia J, Abdulkader I, Lariño-Noia J, Forteza J, Dominguez-Muñoz JE. Histological evaluation of chronic pancreatitis by endoscopic ultrasound-guided fine needle biopsy. Gut 2006; 55: 1661-2.

19. Saftoiu A, Vilman P. Endoscopic ultrasound elastography - a new imaging technique for the visualization of tissue elasticity distribution. J Gastrointestin Liver Dis 2006; 15: 161-5.

20. Giovannini M, Hookey LC, Bories E, Pesenti C, Monges G, Delpero JR. Endoscopic ultrasound elastography: the first step towards virtual biopsy? Preliminary results in 49 patients. Endoscopy 2006; 38: 344-8.

21. Iglesias-García J, Lariño-Noia J, Domínguez-Muñoz JE. Endoscopic ultrasound elastography in the diferential diagnosis of pancreatic solid masses: towards the virtual biopsy. Gastroenterology 2008; 134(Supl. 1): A-47.

22. Janssen J, Schlörer E, Greiner L. EUS elastography of the pancreas: feasibility and pattern description of the normal pancreas, chronic pancreatitis, and focal pancreatic lesions. Gastrointest Endosc 2007; 65: $971-8$.

23. Hirche TO, Ignee A, Barreiros AP, Schreiber-Dietrich D, Jungblut S, Ott $\mathrm{M}$, et al. Indications and limitations of endoscopic ultrasound elastography for evaluation of focal pancreatic lesions. Endoscopy 2008; 40: 910-7.

24. Saftoiu A, Vilmann P, Gorunescu F, Gheonea DI, Gorunescu M, Ciurea $\mathrm{T}$, et al. Neural network analysis of dynamic sequences of EUS elastography used for differential diagnosis of chronic pancreatitis and pancreatic cancer. Gastrointestinal Endoscopy 2008; 68: 1086-94.

\title{
Elastografía ecoendoscópica de segunda generación en el diagnóstico diferencial de las lesiones sólidas pancreáticas. Cáncer de páncreas vs. masa inflamatoria en pancreatitis crónica
}

\author{
J. J. Iglesias García ${ }^{1,2}$, J. Lariño Noia ${ }^{1,2}$, A. Álvarez Castro ${ }^{1,2}$, B. Cigarrán ${ }^{2,3}$ y J. E. Domínguez Muñoz ${ }^{1,2}$ \\ ${ }^{1}$ Servicio de Aparato Digestivo. ${ }^{2}$ Fundación para la Investigación en Enfermedades del Aparato Digestivo. \\ Hospital Clínico Universitario de Santiago de Compostela. A Coruña. ${ }^{3}$ Servicio de Medicina Interna. Hospital Virxe da \\ Xunqueira. Cee, A Coruña
}

\section{RESUMEN}

La ultrasonografía endoscópica (USE) es la técnica más eficaz para el diagnóstico y estadiaje local de los tumores pancreáticos. La asociación de la punción guiada por USE ha permitido aumentar la rentabilidad diagnóstica, si bien es muy explorador dependiente (sin obviar el papel fundamental del patólogo) y no se encuentra exenta de complicaciones. En este contexto la elastografía pancreática emerge como una técnica de gran utilidad que permite evaluar la dureza de los tejidos, mostrando una elevada eficacia diagnóstica en el diagnóstico diferencial de los tumores pancreáticos. La elastografía muestra patrones muy específicos que apoyan la naturaleza maligna o benigna de las lesiones. Sin embargo existe el hándicap de la subjetividad de la interpretación de las imágenes. Recientemente se ha desarrollado la elastografía de $2^{-}$generación que permite realizar un análisis cuantitativo de la elasticidad de los tejidos. Se basa en la determinación de un coeficiente de elasticidad. Nosotros presentamos dos casos que reflejan la utilidad de la elastografía de segunda generación en el diagnóstico diferencial de las lesiones sólidas pancreáticas, en concreto en la di- ferenciación entre un adenocarcinoma de páncreas y una masa inflamatoria en el contexto de una pancreatitis crónica. Se aprecia cómo existen diferencias significativas entre ambas lesiones en el coeficiente de elasticidad (25,46 en el adenocarcinoma de páncreas vs. 2,35 en la masa inflamatoria). Probablemente la elastografía de segunda generación sea una herramienta útil en el diagnóstico diferencial de las lesiones sólidas pancreáticas.

Palabras clave: Ultrasonografía endoscópica. Elastografía. Elastografía de segunda generación. Tumores de páncreas.

\section{INTRODUCCIÓN}

La ultrasonografía endoscópica (USE) se ha convertido en una herramienta fundamental en el estudio de la patología pancreática, siendo considerada como uno de los 
métodos de elección en el diagnóstico y estadiaje local de la patología inflamatoria y de los tumores pancreáticos $(1,2)$. Sin embargo, la diferenciación entre un cáncer de páncreas y una lesión inflamatoria focal, continúa siendo un reto. La USE permite la realización de biopsias dirigidas de las lesiones pancreáticas, alcanzando con una elevada eficacia un diagnóstico cito-histológico (3-7). Sin embargo, la punción guiada por USE es compleja, y en ocasiones se precisan múltiples punciones para poder obtener una muestra adecuada para llegar al diagnóstico definitivo. Por ello, a pesar de ser considerada como muy segura, no se encuentra exenta de complicaciones $(8,9)$.

La elastografía es un método que permite evaluar en tiempo real la dureza o elasticidad de los tejidos, desarrollándose inicialmente en la valoración de órganos superficiales, como la mama (10-13). Las imágenes obtenidas mediante el estudio elastográfico pueden ser consideradas como una aproximación a las características histológicas de las diferentes tejidos analizados (14). La asociación de este tecnología con la USE ha supuesto un avance significativo en el manejo de la patología pancreática, sobre todo en el diagnóstico diferencial de los tumores pancreáticos (15).

Recientemente se ha desarrollado un importante avance, la elastografía de $2^{\mathrm{a}}$ generación. Esta técnica permite no sólo realizar un estudio elastográfico cualitativo, sino también un análisis cuantitativo, basado en la determinación de un coeficiente de elasticidad. Apenas existen datos publicados en la literatura sobre este avance. Nosotros presentamos dos casos que reflejan la utilidad de la elastografía de segunda generación en el diagnóstico diferencial de las lesiones sólidas pancreáticas. Se trata de dos estudios elastográficos de segunda generación, uno en un paciente con un cáncer de páncreas y en otro con una masa inflamatoria en el contexto de una pancreatitis crónica.

\section{MÉTODOS}

Las USE fueron realizadas mediante un ecoendoscopio lineal (EG 3870 UTK; Pentad Europe GmbH, Hamburg, Germany) acoplado al equipo ecográfico EUB 900 (Hitachi Medical Systems GmbH, Wiesbaden, Germany), el cual incluye el modulo de elastografía. Este modulo permite realizar un estudio elastográfico en tiempo real. Se basa en la detección de pequeñas deformidades estructurales obtenidas en la imagen en modo B originadas por la compresión del transductor, de manera que la tensión originada es menor en el tejido duro, con respecto al blando (13). El grado de deformidad se emplea como un indicador de la dureza del tejido $(14,16)$. Los diferentes valores de elasticidad se marcan con diferentes colores, lo que se corresponde con diferentes patrones de elasticidad. El sistema está programado para emplear un mapa de colores (rojo-verde-azul), donde las zonas de tejido más duro se muestran en color azul, las de tejido de dure- za intermedia en color magenta, las intermedias en color amarillo y las más blandas en color rojo (17). Durante la realización de la exploración se puede apreciar en pantalla una doble imagen, en un lado se identifica la imagen básica en modo B, en escala de grises, mientras que en el otro lado de la pantalla se aprecia la imagen obtenida mediante el estudio elastográfico. La elección de la región de estudio se realiza de forma manual, teniendo en cuenta que se debe incluir para el análisis tejido adyacente normal, que servirá como zona de control (15). Para la realización de la elastografía de $2^{\mathrm{a}}$ generación, desarrollada igualmente por Hitachi, se deben seleccionar 2 áreas diferentes ( $\mathrm{A}$ y $\mathrm{B}$ ) dentro la región de interés para poder realizar el análisis elastográfico cuantitativo: área A es representativa de la lesión y B se refiere a una zona blanda de referencia (zona de color rojo en estudio basal). El cociente B/A (coeficiente de elasticidad) se considera como resultado final del estudio.

Para la obtención de las imágenes, la sonda de ecoendoscopia se debe aproximar a la pared del tubo digestivo, aplicando la presión necesaria para obtener una imagen estable y óptima a 7.5 MHz. Dado que las imágenes obtenidas mediante la elastografía tienden a cambiar de color rápidamente, para el realizar el análisis elastográfico debe obtenerse durante el estudio una imagen estable durante al menos 5 segundos.

Una vez que completado el estudio elastográfico, se realizó una punción aspiración con aguja fina guiada por USE de las lesiones pancreáticas con una aguja de 22gauge (Echo-Tip, Wilson-cook Medical, Winston-Salem, North Carolina, USA) para establecer el diagnóstico final de ambas lesiones.

\section{CASOS CLÍNICOS}

\section{Caso 1}

Mujer de 43 años, con antecedentes personales de meningitis en la infancia, diabetes mellitus gestacional y colestasis gravídica. Diagnosticada previamente de una pancreatitis crónica idiopática, ingresa en nuestro servicio por un cuadro de dolor abdominal de localización epigástrico de 48 horas de evolución, asociado a una ictericia obstructiva. Se realizada un TAC abdominal helicoidal con contraste, identificándose la presencia de múltiples calcificaciones pancreáticas, con un aumento de la cabeza del páncreas (alcanza los $6 \mathrm{~cm}$ de diámetro mayor), con pérdida de los planos grasos con duodeno. Existe una discreta dilatación del conducto pancreático principal, así como gran cantidad de adenopatías periaorticocavas y mesentéricas. Se establece el diagnóstico de sospecha de una masa inflamatoria en el contexto de una pancreatitis crónica, sin poder descartar un adenocarcinoma de páncreas. Se realiza una USE, confirmándose la presencia de una masa en cabeza pancreática, heteroecogénica, irregular, mal delimitada, con presencia de calci- 
ficaciones dispersas, tanto en relación con la lesión como en el resto de parénquima pancreático, que presenta un patrón lobular, con puntos y bandas hiperecogénicas (característico de pancreatitis crónica). El conducto pancreático principal se encuentra dilatado, con pared hiperecogénica, patrón irregular y dilatación de colaterales. La lesión pancreática afecta la vía biliar principal, con dilatación secundaria de la misma. Durante la realización de la USE se realiza el estudio elastográfico. En el estudio basal se aprecia un patrón heterogéneo de predominio verde, y en el estudio elastográfico de segunda generación se aprecia un coeficiente de elasticidad de 2,35 y un valor de A (lesión a estudio) de $0,12 \%$. Finalmente se realiza una punción aspiración con aguja fina de $22 \mathrm{G}$, apreciándose hallazgos característicos de una masa inflamatoria en contexto de una pancreatitis crónica (18). Finalmente se realiza una colangiopancreatografía retrógrada endoscópica con colocación de una prótesis de polietileno. La paciente evolucionó de forma satisfactoria, encontrándose tras tres meses de seguimiento, estable y asintomática.

\section{Caso 2}

Varón de 79 años, con antecedentes personales de cardiopatía hipertensiva en fibrilación auricular y carcinoma de células transicionales de vejiga tratado mediante resección transuretral. El paciente fue fumador de unos 20 cigarrillos al día hasta los 70 años y es bebedor de unos 80 gramos de etanol al día. Ingresa en nuestro servicio por un cuadro de dolor abdominal epigástrico, sordo, de unas 3 semanas de evolución, junto con una pérdida ponderal de unos $8 \mathrm{~kg}$ en los últimos 2 meses. Se realizó al ingreso un TAC abdominal helicoidal con contraste, en el que se identifica una lesión irregular en unión cabezacuerpo de páncreas, de aproximadamente $3 \mathrm{~cm}$ de diámetro mayor, con afectación de estructuras vasculares (fundamentalmente el eje porto-mesentérico, con afectación significativa del flujo en estudio doppler) y con adenopatías peripancreáticas y en tronco celiaco, hipoecoicas, redondeadas, mayores de $1 \mathrm{~cm}$, sugestivas de origen tumoral. Se establece el diagnóstico de sospecha de un tumor pancreático, probablemente un adenocarcinoma de páncreas. Se realiza una USE, que confirma la presencia de una lesión sólida en la transición cabeza-cuerpo de páncreas, de aspecto irregular, hipoecoico, con bordes mal delimitados. Se confirma la infiltración vascular descrita en el TAC abdominal. Durante la USE se realiza el estudio elastográfico. En el análisis basal muestra un patrón heterogéneo de predominio azul, con distribución geográfica. En el estudio elastográfico de segunda generación se aprecia un coeficiente de elasticidad de 25,46 y un valor de A (lesión a estudio) de $0,01 \%$. Finalmente se realiza una punción aspiración con aguja fina de $22 \mathrm{G}$, apreciándose hallazgos compatibles con adenocarcinoma de páncreas. El paciente es remitido a Oncología Médica para tratamiento oncológico, al considerarse un tumor irresecable por la afectación vascular y un paciente no operable por la patología cardiológica basal. Tras un seguimiento de 3 meses el paciente se encuentra en progresión tumoral (en último control se objetivó la presencia de metástasis hepáticas) y en tratamiento oncológico paliativo.

\section{DISCUSIÓN}

La elastografía permite evaluar en tiempo real la dureza o elasticidad de los tejidos durante la realización de un estudio ecográfico. Algunas patologías, como los tumores malignos, frecuentemente inducen cambios en las propiedades mecánicas de los tejidos. La elasticidad suele ser uniforme en lesiones benignas; sin embargo, los tumores malignos suelen crecer de forma desorganizada, presentando una elasticidad heterogénea a lo largo del tumor (19). En este contexto, la asociación de esta tecnología con la USE ha supuesto un avance significativo en el manejo, por ejemplo, de la patología pancreática. Ha mostrado su utilidad tanto en el diagnóstico de la pancreatitis crónica como, sobre todo, en el diagnóstico diferencial de los tumores pancreáticos (15).

Hasta el momento actual, existen pocos estudios sobre el papel de la elastografía en el diagnóstico diferencial de las lesiones sólidas pancreáticas. Sin embargo, casi todos ellos tienen el handicap de basarse en la interpretación subjetiva que supone la valoración de un patrón de colores, obtenidos en el estudio elastográfico basal clásico. El primer estudio, publicado por Giovannini y cols., mostró una sensibilidad del $100 \%$ y una especificidad del $67 \%$ para la determinación de malignidad. En su estudio las masas pancreáticas con un aspecto predominantemente azul se consideraban malignas, mientras que otros patrones se consideraban benignos. Fueron capaces de identificar correctamente todos los pacientes con tumores malignos, sin embargo algunas de las lesiones benignas fueron clasificadas como malignas. Propusieron una nueva clasificación basada en el color predominante y el patrón de la imagen (20). Posteriormente, en un estudio realizado por nuestro grupo, en 80 lesiones pancreáticas sólidas y 10 controles sanos, se pudieron identificar cuatro patrones elastográficos diferentes. Uno homogéneo verde, presente sólo en controles sanos; otro heterogéneo de predominio verde, presente en 18 de las 23 masas inflamatorias y en ningún tumor maligno; un tercero heterogéneo de predominio azul, con distribución geográfica, presente en 48 adenocarcinomas y en un tumor metastásico, pero también en 5 lesiones inflamatorias, y un patrón homogéneo azul, asociado sólo a los 8 casos de tumores neuroendocrinos. Con estos hallazgos, la elastografía ecoendoscópica presentó una sensibilidad diagnóstica del 100\%, una especificidad del $78 \%$, con una eficacia global del 93,7\%, en la evaluación de los tumores sólidos pancreáticos (21). Sin embargo, Jan- 
sen y cols. muestran resultados menos optimistas. En el subanálisis que realizan sobre los pacientes con lesiones focales, describen en todos ellos un patrón similar, heterogéneo mixto verde y azul, con distribución irregular, salvo en el caso de tumores endocrinos que presentan patrones más homogéneos, sin embargo sólo incluyen un caso de lesión focal en el contexto de una pancreatitis crónica, siendo difícil comparar con los estudios previos, en los que el número de lesiones inflamatorias es significativamente mayor (22). En esta misma línea, un estudio reciente que incluye 70 pacientes con lesiones sólidas pancreáticas y 10 controles sanos, los autores sólo pudieron completar el estudio elastográfico en el 56\% de los pacientes, fundamentalmente por la dificultad de delimitar en la región de estudio lesiones mayores de $35 \mathrm{~mm}$ o en aquellas alejadas del transductor, al no poder incluir en la región de estudio suficiente tejido normal de control. Obtuvieron una sensibilidad diagnóstica del $41 \%$, una especificidad del $53 \%$ y una eficacia global del $45 \%$, cifras claramente inferiores a la de los estudios previos (23). Sin embargo, en este estudio es criticable el hecho de las 58 lesiones sólidas incluidas en el estudio eran tumores malignos, sin incluir ninguna lesión benigna. De forma global, todos estos estudios presentan una importante limitación, el estar basados en una valoración elastográfica subjetiva, basada en la interpretación de un código de colores. Probablemente este hecho es uno de los factores que pueden influir en estos resultados dispares. Por ello, la posibilidad de realizar una valoración objetiva y reproducible evitaría los sesgos de las interpretaciones subjetivas.

Actualmente se dispone de un sistema que permite la realización de una valoración cuantitativa de la elasticidad de los tejidos, mediante la determinación de un coeficiente de elasticidad, la elastografía de $2^{\mathrm{a}}$ generación. Supone un nuevo e importante avance en diagnóstico diferencial de las lesiones sólidas pancreáticas. Nosotros presentamos en el presente artículo nuestra experiencia inicial. Se trata de dos casos, una masa inflamatoria en cabeza de páncreas y un adenocarcinoma de páncreas, evaluados mediante esta nueva tecnología. Hemos apreciado que el coeficiente de elasticidad obtenido en la lesión inflamatoria es significativamente menor que el caso del adenocarcinoma de páncreas $(2,35$ vs. 25,46). Igualmente también hemos comprobado cómo el valor del área correspondiente con la lesión a estudio (A) es significativamente mayor en el caso de la lesión inflamatoria, con respecto al del caso del adenocarcinoma $(0,12 \mathrm{vs}$. $0,01 \%)$. Parece que es posible diferenciar ambos tipos de lesiones, ya no con la valoración subjetiva de la elastografía de primera generación, sino también de forma objetiva mediante el estudio elastográfico de segunda generación. Es importante destacar que existen otros avances en este mismo sentido. Saftiou y cols. añaden la valoración objetiva mediante el análisis de los histogramas obtenidos del estudio elastográfico convencional. En su serie incluyeron 22 páncreas normales, 11 pacientes con pancreatitis crónica, 32 con adenocarcinomas de páncreas y 3 tumores neuroendocrinos pancreáticos. Empleando un punto de corte de 175 puntos en el histograma, la técnica mostró una sensibilidad diagnóstica del 91,4\%, una especificidad del $87,9 \%$, con una eficacia global del $89,7 \%$ (24).

En conclusión, la elastografía de segunda generación muestra datos alentadores como una herramienta útil en el diagnóstico diferencial de las lesiones sólidas pancreáticas (fundamentalmente en el diagnóstico diferencial entre benignidad y malignidad). En nuestra experiencia inicial hemos obtenido valores significativamente diferentes entre una lesión inflamatoria benigna (en el contexto de una pancreatitis crónica) y una lesión tumoral (adenocarcinoma de páncreas). Sin embargo, son necesarios nuevos estudios prospectivos que permitan confirmar la eficacia de esta técnica en este contexto. 